\title{
Out of the hands of milkmaids
}

\section{From cowpox virus to global disease eradication, a winning strategy we must fight to protect}

n 1914, the year this Journal was founded, there were 59324 cases of diphtheria and 5863 deaths due to this disease in England and Wales. Mass vaccination was introduced in 1942, and by 1957 there were only 37 cases and four deaths. ${ }^{1}$ The situation was relatively similar in Australia. By May 2011, only one fatal case was reported in Australia, in an unvaccinated individual who contracted pharyngeal diphtheria from a friend who acquired the disease overseas. ${ }^{2}$

If I had known of the perils of being a child when I first set foot on this earth, I might have asked for a raincheck - such were the perils from infectious diseases.

In my first years, I dodged the diphtheria bullet and then I was vaccinated. During my childhood there was only triple antigen vaccine, covering diphtheria, pertussis and tetanus. Thus, inevitably, I contracted measles, mumps and chickenpox.

I remember being very sick with measles. So were my two sons, who were born in the 1960s. However, it was not until I was confronted with the situation of a close friend of mine, whose younger daughter contracted subacute sclerosing panencephalitis, that I really saw the impact as the family struggled to cope, watching the terrible decline in an intelligent, ebullient child. In fact, the mother, Gay Davidson, became a public advocate for vaccination when the Minister for Health and Ageing, Michael Wooldridge, committed his energy and funding to a vaccination campaign, even while Australia was in the throes of the 1996 federal Budget cuts.

At primary school, I remember the poliomyelitis epidemic. We still went to school, but interschool sport was curtailed. We were told not to eat icecream. Yet one day, a boy was at school; the next day he was in hospital, and within a week he was dead of poliomyelitis. Morbidity was high, with children in splints or confined to an iron lung.

In the United States, the March of Dimes (a nonprofit organisation originally founded as the National Foundation for Infantile Paralysis by President Franklin D Roosevelt, who himself was afflicted by polio) provided substantial research funding. The Salk vaccine was the eventual product of this funding. ${ }^{3}$ I was in the first cohort to receive the Salk vaccine by injection in my last year at school. Then the oral Sabin polio vaccine appeared and made it far easier to convince the

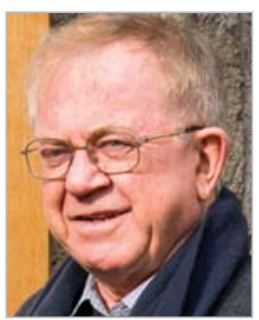

John B Best AO, MD BS, PhD, DSc(Hon) Director of Clinical Training

Murray to the Mountains Intern Training Program Sydney, NSW.

jbbest@iimetro.com.au doi: 10.5694/mjal4.00674 community to take its medicine. Despite the opposition of the March of Dimes bosses who favoured the Salk vaccine, use of Sabin vaccine ultimately prevailed.

My journey through the world of vaccine would not be complete without mention of the oldest vaccination (injecting cowpox virus to protect against smallpox), which gave the whole process its name (from the Latin vaccinus, meaning "from cows"). I needed a smallpox vaccination to go overseas to "the Orient", as it was colourfully then called, on the SS Taiping in 1956. I also needed to have injections to protect against typhoid and cholera. There was no argument - you had to have them because in the world out there, diseases lurked where there was no clean water let alone sewerage.

Smallpox vaccine needed to be administered by a scarification technique, which was later repeated as a requirement for my medical course. Now smallpox is no more. Thanks to people like distinguished virologist Frank Fenner - the centenary of his birth is this year - this disease has been eradicated, and this is one vaccine consigned to history.

Back in the 1950s, vaccinations for overseas travel were compulsory; now, the only compulsory vaccination is that against yellow fever, and only for entry to certain countries if you have recently been in a designated yellow fever area. ${ }^{4}$ The typhoid and cholera vaccinations have been vastly improved, are administered orally and recommended for use only where the chances of contracting the disease are high. ${ }^{5}$ The importance of vaccination against yellow fever was highlighted some years ago by the controversy involving a federal politician when he returned from Venezuela to Australia, having not had a yellow fever vaccination before entering that country. ${ }^{6}$

What of other diseases where vaccination was unavailable? Unfortunately, I missed contracting rubella, but on at least two occasions when my wife was in early pregnancy I was exposed to rubella and suffered the painful injections of gamma globulin into the arms and both buttocks.

Tetanus toxoid has always presented an interesting situation because it is somewhat different. Originally released in 1914, the prime culprit for tetanus is the toxin produced by Clostridium bacteria. Tetanus is the one vaccination that always seems to be given when someone presents with traumatic injury that was contaminated by soil. Again, tetanus has almost been obliterated, however it was interesting to read recently about the New Zealand couple who objected 


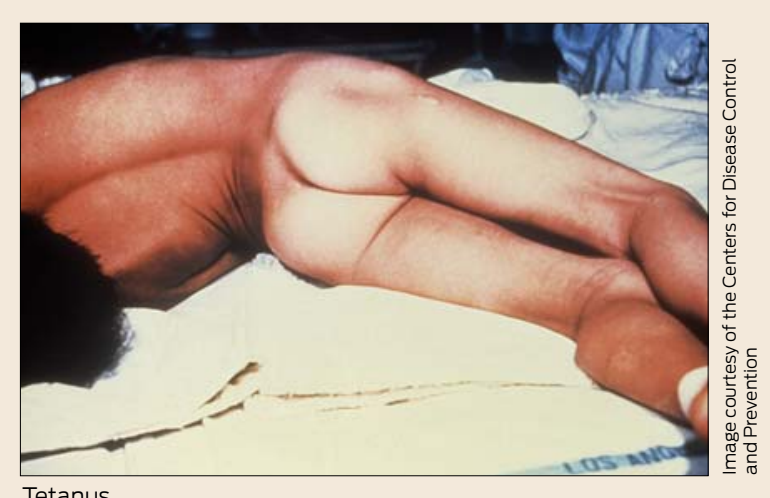

Tetanus

to their children being vaccinated. One of the children contracted tetanus and almost died. This couple's attitude towards vaccination changed overnight when they realised they had underestimated the diseases and totally overestimated the adverse reactions. ${ }^{7}$

I had grown up at the edge of a housing commission area where my father was the local doctor. He appeared one morning with bright yellow sclera and a tawny tinge to his skin; he had contracted infectious hepatitis, which required a time in Fairfield Infectious Diseases Hospital.

Now, as with many other diseases, the whole vaccination schedule has expanded greatly, much to the benefit of the community. The community has nearly covered the microbial waterfront.

Paediatrics has changed markedly over the 100 years in which the Journal has been published. Yet, in this community, we have large numbers of confused and deluded parents who resist having their children vaccinated, which not only puts those children at risk, but, if the immunisation rate falls sufficiently, puts entire communities at risk.
There are legitimate scientific reasons for not vaccinating a very small proportion of people. Such people should be protected by other therapeutic means.

However, there is no place for "conscientious objection" to vaccination. I received my first vaccinations when the world was at war and conscientious objection meant not wanting to bear arms. Now the conscientious objection under discussion is metaphorically not wanting to bare arms in a war against disease and disability.

Wilful objection to vaccination on the basis of spurious science should neither be encouraged nor rewarded, particularly by government. It is time for the whole question of conscientious objection to vaccination to be aired in Parliament if for no other reason than to find out which of our politicians are against vaccination, for they are as dangerous to continued Australian wellbeing as anyone who would challenge the biosecurity of our country.

Competing interests: No relevant disclosures.

Provenance: Commissioned; not externally peer reviewed.

1 Bonnet JM, Begg NT. Control of diphtheria: guidance for consultants in communicable disease control. Commun Dis Public Health 1999; 2: 242-249.

2 Australian Government Department of Health. Communicable Diseases Network Australia. National communicable diseases surveillance report. Fortnight 10, 2011 summary notes for selected diseases. 7 to 20 May 2011. http://www.health.gov.au/internet/main/publishing.nsf/Content/A7F77C 845B9C93DICA257BF0001C95Fl/\$File/nndssreport-fn10-11.pdf (accessed May 2014)

3 March of Dimes. A history of the March of Dimes. The polio years. http:// www.marchofdimes.com/mission/a-history-of-the-march-of-dimes.aspx (accessed May 2014).

4 Australian Government Department of Health. Yellow fever - general fact sheet. http://www.health.gov.au/yellowfever (accessed Jun 2014).

5 The Australian immunisation handbook. 10th ed. Canberra: Australian Government Department of Health, 2013.

6 Mahoney D. Beal: bend the rules and people exploit it. Canberra Times 1988; 25 Jul: 1. http://trove.nla.gov.au/ndp/del/article/102034407 (accessed Jun 2014).

7 Wynne E. Parents' fear of vaccinations nearly killed their son. $720 \mathrm{ABC}$ Perth. 2013; 6 Jun. http://www.abc.net.au/local/stories/2013/06/06/3776327. htm (accessed May 2014). 